Z. Klin. Chem. Klin. Biochem.

13. Jg. 1975 , S. $381-386$

\title{
On the Fluorimetric Determination of Oestriol in Pregnancy Urines after Thin Layer Chromatography
}

\author{
By M. van Bezeij and M. W. Bosch
}

From the department of clinical chemistry, St. Joannes de Deo Hospital, Velserstraat 19, Haarlem (The Netherlands)

(Eingegangen am 21. August 1974/1. April 1975) Summary: An improved method is described for the determination of oestriol concentrations in urines of pregnant
women.

Oestriol is detected as a derivate of 1-dimethylaminonaphtalene-5-sulphonylchloride (DANSYLchloride). The method has the following characteristics:

1. The recovery of oestriol-16-glucuronide is $94 \%$.

2. For the interpretation of the results obtained with this method mean values and $95 \%$ probability bounds of urinary oestriol excretion for each week of the last three months of pregnancy are given. (e.g. 49-125 $\mu \mathrm{mol} / 24 \mathrm{~h}$ at 32 weeks of gestation, $108-238 \mu \mathrm{mol} / 24 \mathrm{~h}$ at 40 weeks.)

3. The coefficient of variation of the method is $4 \%$ (from day to day)

4. The lowest detectable concentration is $3 \mu \mathrm{mol} / 1$.

5. Influence of glucose can be eliminated.

6. Other urinary compounds have no influence on the determination.

\section{Fluorimetrische Bestimmung von Östriol im Schwangerenharn nach Dünnschichtchromatographie}

Zusammenfassung: Eine verbesserte Methode für die Bestimmung von Östriol im Schwangerenharn wird beschrieben. Östriol wird als Derivat von 1-Dimethylaminonaphthalin-5-sulfonylchlorid (DANSYLchlorid) detektiert. Die Methode hat folgende Charakteristika:

1. Die Wiederfindung von Östriol-16-glucuronid beträgt $94 \%$.

2. Zur Interpretation der mit dieser Methode erhaltenen Ergebnisse werden Mittelwerte und 95\%-Wahrscheinlichkeitsgrenzen der Östriolausscheidung im Harn für jede Woche des letzten Trimenons angegeben (32. Schwangerschaftswoche $49-125 \mu \mathrm{mol} / 24 \mathrm{~h} ; 40$. Schwangerschaftswoche $108-238 \mu \mathrm{mol} / 24 \mathrm{~h}$ ).

3. Die Präzision von Tag zu Tag beträgt VK $=4 \%$.

4. Die Nachweisgrenze beträgt $3 \mu \mathrm{mol} / 1$

5. Der Einfluß von Glucose kann vernachlässigt werden.

6. Andere im Harn vorhandene Verbindungen stören die Bestimmung nicht.

\section{Introduction}

The plasma and urinary oestriol levels have proved to be the most useful tests for foeto-placental function (1).

Many methods have been developed for the determination of urinary oestriol levels. In most methods total oestrogens are determined by formation of Kober chromogens, relying on the observation that oestriol is the most important component of the oestrogens in pregnancy urine (2). In more specific determinations the formed Kober chromogens are extracted in organic solvents followed by fluorimetric estimation $(3,4)$. Specific determinations of oestriol have also been developed, e.g. formation of Kober chromogens after gelfiltration (5), gas-liquid chromatography (6) and thin layer chromatography (7).

In the method of $D v i r$ (7) a quite different way of detection was applied. Oestriol was estimated in a fluorescence spectrophotometer as 1-dimethylaminonaphthalene-5-sulphonyloestriol (DANSYLoestriol). By choosing this method for our routine investigations we hoped to avoid all the problems, accompanying the 
formation and estimation of Kober chromogens. However because of bad separation results and tailing during the thin layer chromatography, the method needed modification. In his review of the methods for the determination of oestrogens in urines - most of them are based on the Kober reaction - Runnebaum (8) describes an accuracy factor for oestriol of $54-85 \%$ for the best of these methods. In neither of these methods, nor in the methods mentioned above (2-7) were oestriolglucuronides used for accuracy tests.

As the determination of the recoveries of oestriolglucuronides is the only way of testing the reliability of a method - the urinary oestrogens exist during pregnancy as $95 \%$ of oestriol-16-glucuronide - we examined these recoveries for the method described in this paper.

As Runnebaum (8) mentions, every method has its own normal values. Accuracy values differ from method to method. The loss of oestriol is not.considered in the calculation of these normal values. Therefore mean values and $95 \%$ probability bounds, obtained with the thin layer chromatographic method, for the last three months of pregnancy are given.

\section{Materials and Methods}

1. 1-dimethylamino-5-sulphonylchloride (DANSYLchloride), Aldrich Europe, Beerse, Belgium. It should be stored at $5{ }^{\circ} \mathrm{C}$. Because this compound appears to be unstable in air exposure to the air should be as short as possible.

A solution of $2 \mathrm{~g} / 1$ in acetone was made.

2. Buffer solution ( $\mathrm{pH} 10.5$ ) was prepared by mixing $100 \mathrm{ml}$ sodium bicarbonate $(80 \mathrm{~g} / \mathrm{l})$ with approximately $15 \mathrm{ml}$ sodium hydroxide ( $5 \mathrm{~mol} / \mathrm{l}$ ) and adjusting the $\mathrm{pH}$ exactly (using a $\mathrm{pH}$ meter) with sodium hydroxide. A one to ten dilution of the buffer is used.

3. Oestriol-3-( $\beta$-D-glucuronide), oestriol-16 $\alpha$-( $\beta$-D-glucuronide) and oestriol-17 $\beta$-( $\beta$-D-glucuronide) were obtained from Sigma chemical company, St. Louis, U.S.A.

4. Oestriol, Merck, Darmstadt, Germany.

A solution of $10 \mathrm{mg}$ in $100 \mathrm{ml}$ ethanol was made.

5. Merck DC Kieselgel Alufolien $20 \times 20 \mathrm{~cm}$, Merck, Darmstadt, Germany.

6. Pregnancy Oestrogens Kit, Searle Diagnostic, High Whycombe, England.

7. Freeze-dried pregnancy urine, International Diagnostic Aids Limited, Portslade, Sussex, England.

8. All further chemicals were of analytical grade.

\section{Apparatus}

Perkin-Elmer fluorescence spectrophotometer 204

Subjects

Twenty four hour urine collections were made seven days a week by hospitalised and non hospitalised patients. As urine collection is difficult even in hospital, special attention was paid to the reliability of the collection. For the calculation of "normal values" patients were accepted if they had a regular spontaneous menstruation before pregnancy and were certain of the last date of menstruation. Diabetic patients and patients who showed hypertension (more than $140 / 90 \mathrm{~mm} \mathrm{Hg}$ ) were not accepted as normal. Only if the child's weight was classified as normal according to the scale of Thomson (9) and the baby was in good condition was the case accepted as normal.
79 of the 184 researched patients fitted these criteria. The average weekly values were used for the calculation of "normal values".

For the estimation of the correlation between birth weight and highest oestriol value (average weekly value) there was no restriction for acceptance if the child was in good health after birth.

Five cases of women who suffered intrauterine foetal death are presented.

Two patients are selected to show the patient-dependent day to day variation. Patient $\mathbf{A}$ was hospitalised on indication of hypertension; a slight glucose intolerance was developed during pregnancy; and the patient's child was born at 38 weeks with a weight of $3280 \mathrm{~g}$. There is no explanation for the day to day variation. Patient $\mathrm{B}$ was hospitalised on indication of hydramnion, hypertension, oedema and very strong discongruence between placenta function (oxytocinase and human phacental lactotropin) and urinary oestriol. At 36 weeks hydramnion increased strongly. At 38 weeks twins were born, one of which was anencephalic. The other was a normal child of $2200 \mathrm{~g}$.

This patient showed only very little day to day variation.

\section{Methods}

Probably because of the salt content of the applied extract in the Dvir (7) method, the mobile phase did not easily move through the applied spot, and one sometimes found the spot surrounded by but not sufficiently wetted by the mobile phase. This effect produces severe distortions in the solvent-solute front.

The final procedure is as follows:

From 24 hour specimens $2 \mathrm{ml}$ were diluted with distilled water to $12 \mathrm{ml}$. As a standard $800 \mu \mathrm{l}$ of the oestriol solution $(80 \mu \mathrm{g}$ oestriol) were diluted to $12 \mathrm{ml}$ with water. After adding $5 \mathrm{ml}$ of concentrated hydrochloric acid and boiling under reflux for 30 minutes the mixtures were extracted with $50 \mathrm{ml}$ of diethylether. The ether phases were washed with $8 \mathrm{ml}$ of sodium bicarbonate solution $(80 \mathrm{~g} / \mathrm{l})$, followed by $10 \mathrm{ml}$ of distilled water. The ether extracts were dried over anhydrous sodium sulphate. $25 \mathrm{ml}$ of the extracts were evaporated to dryness in a waterbath at $60^{\circ} \mathrm{C}$. The residues were dissolved in $400 \mu \mathrm{l}$ of buffer solution $\mathrm{pH}$ 10.5. $400 \mu \mathrm{l}$ of DANSYLchloride solution were added. After mixing during 20 seconds the mixtures were allowed to stand at room temperature for 15 minutes and placed in a waterbath $\left(85^{\circ} \mathrm{C}\right)$ for 20 minutes.

After cooling, $3 \mathrm{ml} 0.5 \mathrm{~mol} / 1$ sodium hydroxide solution and $6 \mathrm{ml}$ diethylether were added. After mixing for 20 seconds, using a Vortes mixer, the water phase was removed by suction. The ether phase was dried on anhydrous sodium sulphate. $3 \mathrm{ml}$ of the ether phase was evaporated to dryness in a water bath $\left(60^{\circ} \mathrm{C}\right)$. The residue was dissolved in $250 \mu \mathrm{l}$ of chloroform.

$20 \mu \mathrm{l}$ of the chloroform solution was spotted on the silica gel sheets, then activated by heating for 30 minutes at $120^{\circ} \mathrm{C}$. After chromatography over $15 \mathrm{~cm}$, performed with a mixture of benzene and ethanol $(85: 15)$, as suggested by Keller $\left.{ }^{1}\right)$, the spots of D'ANSYLoestriol were visualised by ultraviolet light. The spots were cut out and eluted with $3 \mathrm{ml}$ methanol. The fluorescence intensities were measured in a fluorescence spectrophoțometer (exciter $346 \mathrm{~nm}$, analyser $525 \mathrm{~nm}$ ).

\section{Results}

\section{Specificity}

None of the other urine compounds influence the formation of the DANSYLderivates, since recoveries of the oestriol-16-glucuronide from water and urines show no difference (tab. 1).

\footnotetext{
1) M. Keller personal communication.
} 
Tab. 1. Recoveries of oestriol glucuronides

$250 \mu \mathrm{l}$ of ethanolic solutions, containing oestriol glucuronides about $500 \mu \mathrm{mol} / \mathrm{l}$ were added to $1.75 \mathrm{ml}$ of water or urine.

\begin{tabular}{|c|c|c|c|c|c|}
\hline Compound & $\begin{array}{l}\text { Added } \\
{[\mu \mathrm{mol} / 1]}\end{array}$ & $\begin{array}{l}\text { Found } \\
{[\mu \mathrm{mol} / 1]}\end{array}$ & $\begin{array}{l}\text { Recov- } \\
\text { ery } \\
\%\end{array}$ & $\begin{array}{l}\text { Number } \\
\text { of } \\
\text { analyses }\end{array}$ & $\begin{array}{l}\text { C.V. } \\
{[\%]}\end{array}$ \\
\hline & & water urine & & . & \\
\hline $\begin{array}{l}\text { Oestriol-3- } \\
\text { glucuronide }\end{array}$ & $\begin{array}{l}41.5 \\
41.5\end{array}$ & $\begin{array}{ll}38.5 & \\
& 39.0\end{array}$ & $\begin{array}{l}90 \\
94\end{array}$ & $\begin{array}{l}2 \\
2\end{array}$ & \\
\hline $\begin{array}{l}\text { Oestriol-17- } \\
\text { glucuronide }\end{array}$ & $\begin{array}{l}49.5 \\
49.5\end{array}$ & $\begin{array}{ll}37.5 & \\
& 38.5\end{array}$ & $\begin{array}{l}77 \\
79\end{array}$ & $\begin{array}{l}2 \\
2\end{array}$ & \\
\hline $\begin{array}{l}\text { Oestriol-16- } \\
\text { glucuronide }\end{array}$ & $\begin{array}{l}60.6 \\
60.6\end{array}$ & $\begin{array}{ll}57.5 & \\
& 57.0\end{array}$ & $\begin{array}{l}95 \\
94\end{array}$ & $\begin{array}{r}6 \\
10\end{array}$ & $\begin{array}{r}15.1 \\
9.5\end{array}$ \\
\hline
\end{tabular}

Glucose has some influence on the acid hydrolysis. The loss of oestriol is dependent of the glucose concentration. If all conditions of the hydrolysis are standardised, corrections can be made.

By adding yeast (Saccharomyces cerevisiae) to a glucose containing urine and incubation for $30 \mathrm{~min}$ at $37^{\circ} \mathrm{C}$, glucose can be removed. After centrifugation samples are taken from the supernatant. No loss of oestriol could be found.

Oxosteroids (aetiocholanolone, androsterone, 11-hydroxyaetiocholanolone, 11-hydroxyandrosterone and dehydroepiandrosterone) at concentrations of $100 \mathrm{mg} / \mathrm{l}$ were added to the urines. They have no influence at all. Pregnanediol, in the same concentration, also had no influence.

\section{Reproducibility}

The reproducibility was examined by analysing four freeze-dried pregnancy urines on different days (precision from day to day) and by analysing mâny urines in duplicate (precision in the series). Results are shown in tables 2 and 3.

Tab. 2. Results of the analysis of 4 freeze-dried pregnancy urines. Readings were made on different days

\begin{tabular}{lllr}
\hline Oestriol & & & \\
$\bar{x}$ & S.D. & C.V. & N \\
{$[\mu \mathrm{mol} / 1]$} & {$[\% \mathrm{~mol} / 1]$} & {$[\%]$} & \\
\hline 20.4 & 0.9 & 4.4 & 12 \\
23.8 & 0.9 & 3.8 & 6 \\
53.3 & 2.5 & 4.7 & 18 \\
62.9 & 2.5 & 3.8 & 10 \\
\hline
\end{tabular}

$\mathrm{N}=$ number of days on which specimens were analyzed

Tab. 3. Results of duplicate determinations of oestriol

\begin{tabular}{rcccl}
\hline $\mathrm{N}$ & $\begin{array}{l}\text { Range } \\
{[\mu \mathrm{mol} / 24 \mathrm{~h}]}\end{array}$ & $\begin{array}{l}\text { Average level } \\
{[\mu \mathrm{mol} / 24 \mathrm{~h}]}\end{array}$ & $\begin{array}{l}\text { C.V. } \\
{[\%]}\end{array}$ \\
\hline 34 & $34-66$ & 50 & 3.3 & 6.5 \\
64 & $67-100$ & 83,5 & 3.6 & 4.3 \\
30 & $101-133$ & 117 & 3.7 & 3.2 \\
4 & $134-166$ & 150 & 4.0 & 2.7 \\
\hline
\end{tabular}

\section{Sensitivity}

Dilutions of a pregnancy urine were made in duplicate. The oestriol levels were determined. Results are shown in figure 1. The relation between dilution and oestriol level is linear. The lowest detectable concentration is $3 \mu \mathrm{mol} / 1$ (calculated from duplicate determinations by estimation of the $S_{y x}$ of the standard line)

\section{Recovery}

The recoveries of added oestriol glucuronides to water and pregnancy urine were studied. The oestriol glucuronides studied were oestriol-3 $\beta$-(D-glucuronide), oestriol-16 $\alpha$-( $\beta$-D-glucuronide) and oestriol-17 $\beta$ - $(\beta$-Dglucuronide). The experiments with the 3- and 17 . glucuronides were made in duplicate.

As the 16-glucuronide is the most important of the three, more determinations with this glucuronide, added to water and pregnancy urines were made. There is no difference in the recoveries from water and those from urine. Results are shown in table 1.

\section{Interpretation of the values}

Mean values and standard deviations were calculated from the average values per week, obtained from 79 pregnant women. Results are shown in figure 2.

The height of the measured urinary oestriol values before birth appeared to be dependent of the baby's weight. In figure 3 the regression line of this comparison is shown with the limits of $95 \%$ reliability. Using this figure, the weight the baby will minimally have at birth can be prognosticated.

In five cases very low urinary oestriol values corresponded with foetal death in utero. Specification of these cases is given in table 4 .

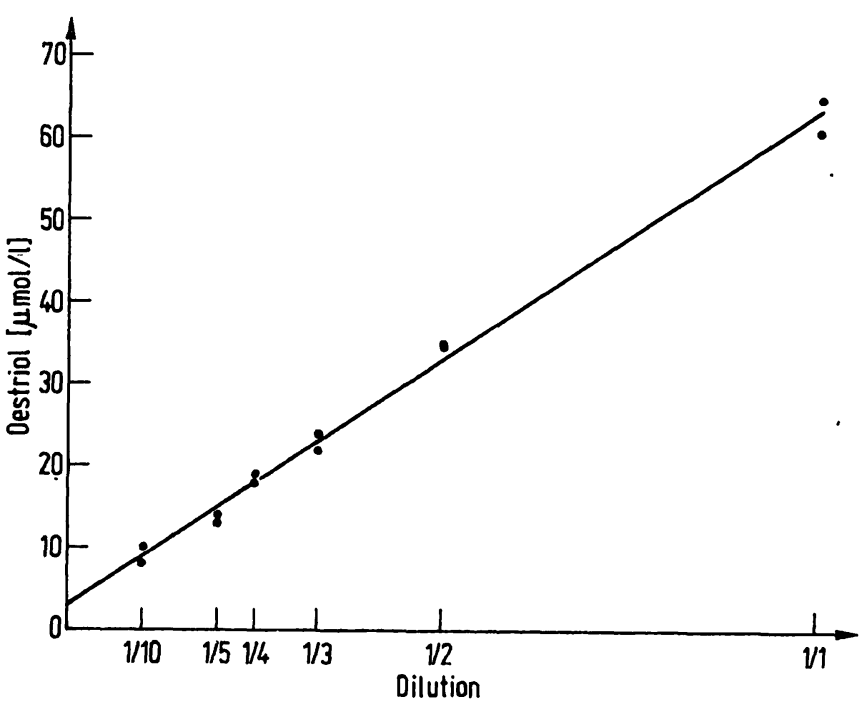

Fig. 1. Recoveries of dilutions of a pregnancy urine 


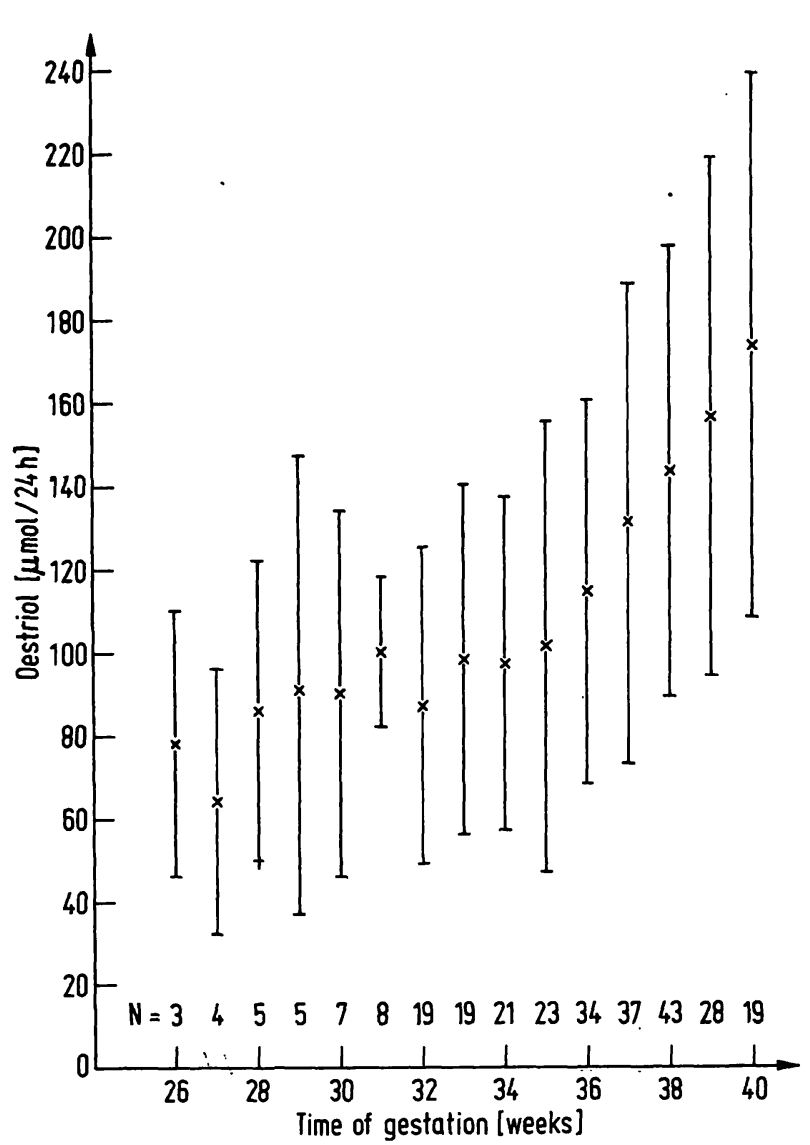

Fig. 2. Mean values and $95 \%$ probability bounds of urinary oestriol excretion for the last three months of pregnancy. 275 average weekly values, obtained from 1925 samples were used for the calculation.

$\mathbf{N}=$ number of patients

$\mathrm{X}=$ mean value

$I=$ mean value \pm 2 S.D. .

Tảb. 4. Subnormal urinary oestriol values obtained from five patients suffering from intrauterine foetal death.

\begin{tabular}{lll}
\hline Patient no. & Weeks of gestation & $\begin{array}{l}\text { Urinary oestriol } \\
{[\mu \mathrm{mol} / 24 \mathrm{~h}]}\end{array}$ \\
\hline 1 & 26 & 15 \\
2 & 28 & 10 \\
3 & 31 & 13 \\
4 & 31 & 16 \\
5 & 35 & 34 \\
\hline
\end{tabular}

There existed an individual day to day variation in several cases, while other cases in the same period did not show this variation. The average weekly values however, hardly give a fluctuating pattern when they are plotted against the time. Figure 4 illustrates two cases. One with and one without a day to day variation.

\section{Comparison with an absorptiometric method}

With the method described at least 3-4 hours are required before the gynaecologist can have the results. Therefore we decided to look for another method for

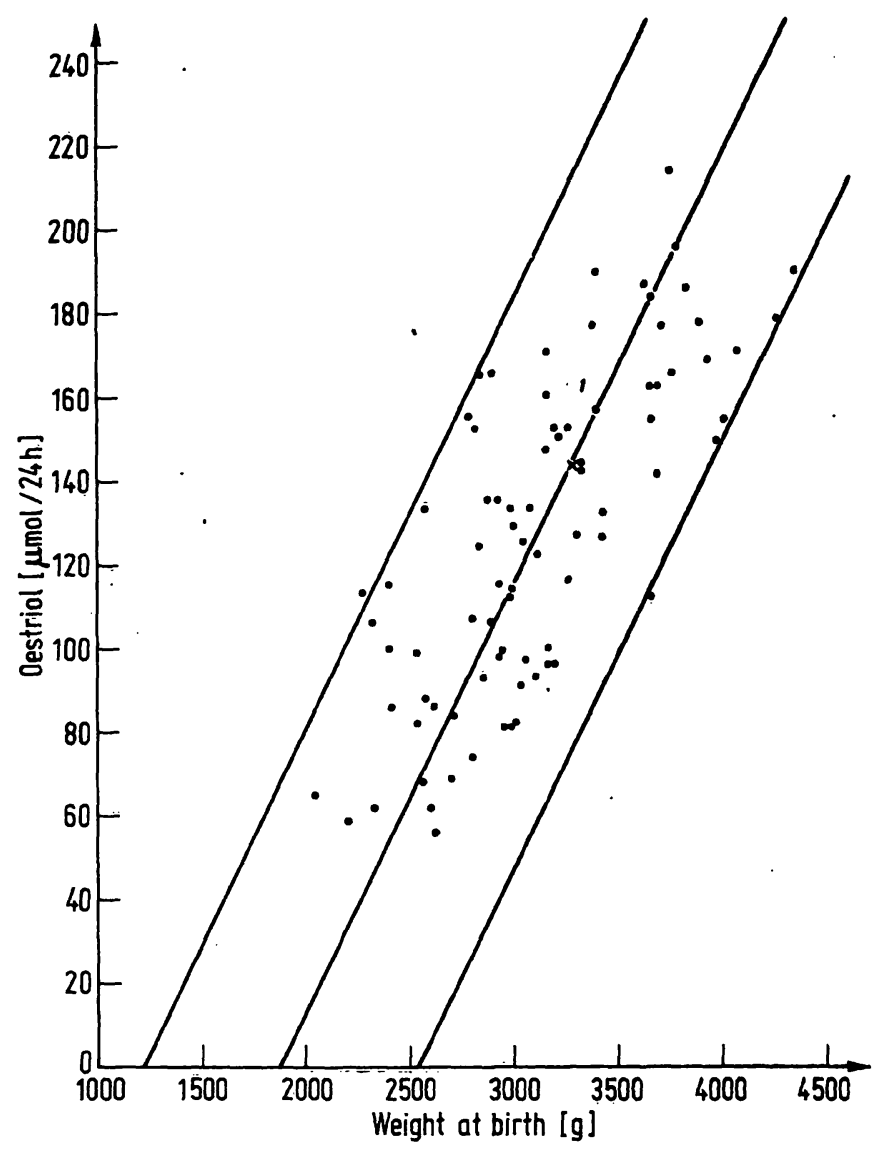

Fig. 3. Comparison of the baby's weight and the height of the final week's urinary oestriol value. $y=0.103 x-194, r=0.75$, $S_{x y}=34 . N=84, \bullet=1 x ; x=2 x$

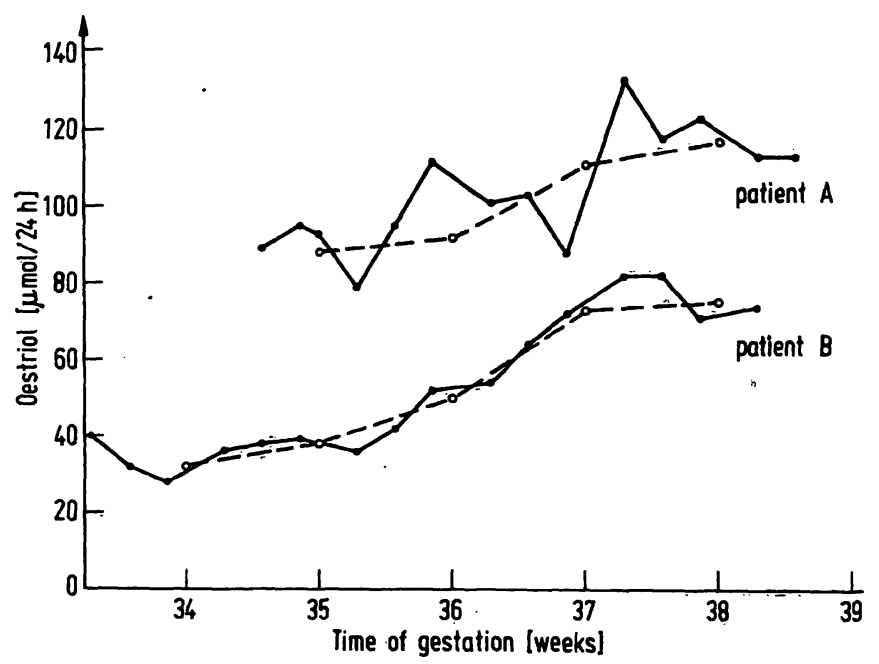

Fig. 4. Day to day variations shown by two patients

- = daily value

$0=$ average weekly value

urgent cases. We chose a simple, commercial available method (Searle Diagnostics). This method is based on the formation of Kober chromogens after enżymatic hydrolysis. The reaction was carried out following the instruction manual. The colour was measured in a spectrophotometer at $514 \mathrm{~nm}$. The Allen correction (9) was carried 
out. As a result of the comparison a regression line could be calculated: $y=4,87+0,77 \times(N=79)$. The correlation coefficient is 0.86 (absorptiometric method $y$, thin layer chromatographic method $\mathrm{x}$ ).

Nevertheless the recovery of oestriol-16-glucuronide added to pregnancy urine was very disappointing (35\%). The recovery of oestriol was $72 \%$, which is in good accordance with the formula of the regression line (readings were made in duplicate).

\section{Discussion}

Many methods $(2,3,4,5)$ depend on the formation of Kober chromogens. A lot of substances have great influence on the formation of these chromogens and cause suppression of the colour formation and quenching of the fluorescence of these chromogens. These substances vary from day to day. The follow-up of the patient's values becomes difficult and the curves (urinary oestriol/ day) tend to have an individual character and cannot be compared with those of other patients. Absolute values can hardly be obtained. Individual day to day variation is not only due to the patient's fluctuation, but also to these influences. For this reason we chose, after using the method of Brombacher (4) for several years, the method described. None of the authors, mentioned above, give information of the recoveries of oestriol glucuronides. Normal values are given by only two of them (2.5) (without mentioning the way of selecting their patients).

Dvir's (7) method did not give in our hands the results we expected. By a better way of preparing the extracts and the use of a different mobile phase we achieved good separation of the DANSYLoestriol and we avoided tailing in this important part of the chromatogram. By using Alufolien quantitative elution of the spot is no problem.

In our method we found good recoveries from pregnancy urines for the oestriol-16-glucuronide (94\%). As this reagent is a very expensive one, it could not be used as a standard. Thanks to the Dutch Health Institute (Rijks Instituut voor de Volksgezondheid, Bilthoven, The Netherlands) it will be available for routine analysis now for a reasonable price.

From the Rijks Instituut voor de Volksgezondheid we received the message that oestriol-16-glucuronide is commercially available for a reasonable price now from Ikapharm, Israël (purity at least $95 \%$ ). The Institute renounces the distribution of this standard.

Recoveries of 3-and 17-glucuronides were comparable with those of the 16-glucuronide.

Other urinary substances have no influence on the reaction with the DANSYLchloride. Spots of the oestrone and oestradiol derivates can be seen on the chromatogram. Oxosteroids and pregnanediol have no influence at all. They form no DANSYLderivates, as the DANSYLchloride reacts with phenolic alcohols only.

Glucose has influence on the acid hydrolysis. However it can be removed by yeast.

Medicaments do not interfere with the determination. Dydrogesterone, for example, which is frequently used in our clinic gives a blue fluorescing spot separated from the ocstrogens.

The method has one disadvantage. The analysis of one specimen requires a time of at least 3 hours. As hydrolysis and extraction need time, greater series require more time before the results are known. Chromatography is the most time consuming step. For this reason we compared the method with the quick method, based on the formation of Kober chromogens. The results of the comparison showed that the chromatographic method should be preferred in spite of the time consumption. The differences in the values obtained in these two methods tended, as expected, to be patient-dependent. The recovery of oestriol-16-glucuronide was low in the absorptiometric method.

In conclusion, it can be said after two years of routine analysis of urinary oestriol by this means, that the method proved to be reliable and accurate, and without problems. It needs no expensive apparatus. Thin layer chromatography, as a basic step for purification and separation makes the method highly specific and has almost no limitation in the number of analyses for one day.

\section{Acknowledgements}

We wish to thank Mrs. O. van der Klis and Mr. $H$. de Bruin for their technical assistence. We also wish to thank Miss $M$. Veltkamp of the department of gynaecology and obstetrics, St. Joannes de Deo Hospital, Haarlem (L. Vasen and M. Driessen gynaecologists) for medical documentation of the investigated cases. 


\section{References}

1. Watson, D., Siddiqui, S. A., Stafford, J. E. H., Gibbard, S. \& Hewitt, V. (1973), J. Clin. Pathol. 26, 249-300.

2. Oakey, B. E., Bradshaw, L. R. A., Eccles, S. S., Stitch, S. R. \& Heys, R. F. (1967), Clin. Chim. Acta 15, 35-45.

3. Brown, J. B., Macleod, S. C., Macnaughtan, C., Smith, M. A. \& Smyth, B. (1968), J. Endocrinol. 42, 5-15.

4. Brombacher, P. J., Gijzen, A. H. J. \& Verhesen, P. E. (1968), Clin. Chim. Acta 20, 360-361.

5. Van Tilburg, A. M. J. \& Muller, Ch. J. (1970), Clin. Chim. Acta 29, 5-14
6. Van de Calseyde, J. F., Scholtis, R. J., Schmidt, N. A. \& Kuypers, A. M. J. (1969), Clin. Chim. Acta 25, 345-349.

7. Dvir, R. \& Chayen, R. (1969), J. Chromatogr. 45, 76-81.

8. Runnebaum, B. \& Holzmann, K. (1970), this J. 8, 345-353.

9. Thomson, A. M. \& Billewicz, W. Z. (1968). J. Obstet. Gynaecol. Brit. Cwlth. 75, 903-916.

10. Allen, W. M. (1950), J. Endocrinol. 10, 71-83.

Drs. M. van Bezeij,

Ziekenhuis St. Joannes de Deo, Klinisch chemisch laboratorum, Velserstraat 19

Haarlem

The Netherlands 